\title{
Knowledge organization and ISKO: state, demands, ideals
}

La organización del conocimiento y la Sociedad Internacional

para la Organización del Conocimiento: estado, demandas, ideales

\section{H. Peter OHLY}

ISKO Vice-president, Peter.Ohly@gmx.de

\begin{abstract}
Resumen
Durante la decimotercera conferencia de la Sociedad Internacional para la Organización del Conocimiento (ISKO), celebrada en 2014 en Cracovia (Polonia), tuvo lugar una discusión sobre "El futuro de la Organización del Conocimiento". Se presenta una sinopsis crítica del panel desde la perspectiva de uno de los participantes. Los temas fundamentales fueron: ¿Qué es la organización del conocimiento? ¿Cuáles serán los retos más sobresalientes para ISKO y la organización del conocimiento en el futuro? ¿Cuál es su imagen ideal de ISKO y la organización del conocimiento en el futuro? Se concluyo, entre otras cosas, que la organización del conocimiento es una disciplina de carácter general aplicable en muchas áreas, aunque mayormente se percibe como una parte de la ciencia de la información y la biblioteconomía. Para mejorar su situación es necesario abordar no sólo sus fundamentos teóricos, sino también sus diversos campos de aplicación, abriéndose a nuevos objetos y métodos. La integración de la diversidad cultural y semántica debe verse como un aspecto importante en una situación politélica.
\end{abstract}

Palabras clave: ISKO. Organización del conocimiento. Sistemas de organización del conocimiento. Ciencia de la información. Biblioteconomía. Tendencias.

\section{Introduction}

The $13^{\text {th }}$ international ISKO conference titled "Knowledge Organization in the 21st Century: Between Historical Patterns and Future Prospects' was held in Krakow in May 2014. With respect to the 25th Anniversary of ISKO and Knowledge Organization, Rebecca Green, Assistant Editor for the Dewey Decimal Classification at Online Computer Library Center (OCLC), moderated a panel on 'The Future of Knowledge Organization and ISKO'. She understood this panel as a platform for discussing knowledge organization in the past, present, and future within ISKO. The statements of the panelists and the audience were worked out and published in the bi-monthly Journal of the International Society for Knowledge Organization (KO) by Green (2014). Here a synopsis with addition-

\begin{abstract}
On the $13^{\text {th }}$ conference of the International Society for Knowledge Organization (ISKO) 2014 in Krakow a panel was held on 'The Future of Knowledge Organization and ISKO'. Here a synopsis with additional information and more dense presentation is given by a panelist. The main items were: What is knowledge organization (KO)? What will be the most challenging for ISKO and KO in the future? What is your ideal picture of ISKO and KO of the future? The results were inter alia that $\mathrm{KO}$ is a general discipline and applicable in many areas, though it is mostly perceived as part of information and library science. To ameliorate its standing, not only the fundamentals have to be worked out but also its diverse application fields and openness to new objects and methods. To integrate cultural and semantic diversity has to be seen as an important point in a polytely situation.
\end{abstract}

Keywords: ISKO. Knowledge organization. Knowledge organization systems. Library science. Trends.

al information and a more dense presentation of the published part will be given by one of the panelists.

Participants of the panel were: Joseph Tennis, Univ. Washington, Information School, Associate Professor (new ISKO President 2014-2018), Vera Dodebei, Chair of the Brazilian ISKO, Federal University of Rio de Janeiro, Graduate Program in Library Science, $\mathrm{PhD}$ in Communication and Culture, Rosa San Segundo, Chair of the Spanish ISKO, University Carlos III Madrid, Director of the Department of Library and Information Science, Associate Professor, Wiesław Babik, Chair of the Polish ISKO, Jagiellonian University of Krakow, Institute of Information and Library Science, Associate Professor, Peter Ohly, ISKO President 2010-2014, Social Scientist (formerly at GESIS - Leibniz-Institute for the Social Sciences in Germany), Amos David, 
Chair of the French ISKO, Lorraine University of Nancy, Research Laborarory of Communication Sciences and Applications, Professor of Information Science and Communication, and Claudio Gnoli, Webmaster of ISKO, University of Pavia, Mathematics Department Library, Natural Scientist.

The discussion was amended by the audience, namely: Ingetraut Dahlberg, Founder of German Classification Society and of ISKO, PhD in Linguistics, Grant Campbell, Univ. Western Ontario, Faculty of Inform. and Media Studies, Assistant Professor, Dagobert Soergel, University of Buffalo, Department of Library and Information Studies, Prof. Emeritus, Inform. Studies, María Lopez-Huertas, ISKO President 2006-2010, Univ. Granada, School of Library and Information Science, Professor, Jill McTavish, Librarian at London Health Sciences Centre, Ontario, and Laura Ridenour, University of WisconsinMilwaukee, MA.

The International Society for Knowledge Organization (ISKO) denotes itself "the premier international scholarly society devoted to the theory and practice of knowledge organization" (ISKO, 2004-). ISKO charter lists as ISKO's aims (ISKO, 1989):

[...] to promote research, development and application of all methods for the organization of knowledge in general or of particular fields by integrating especially the conceptual approaches of classification research and artificial intelligence. The Society stresses philosophicological, psychological and semantic approaches for a conceptual order of objects $[\ldots]$

With reference to these aims Rebecca Green posed more or less these three questions to the panelists (1): 1) What is knowledge organization (KO)? 2) What changes do you foresee in the future that will prove to be the most challenging for ISKO? 3) What is your ideal picture of what the ISKO of the future could be? How do we get there?

\section{What is knowledge organization (KO)?}

Green introduces this question by a critical statement:

In Dewey [Decimal Classification] the rule of application instructs us to class a work on, say, a thesaurus of architecture - that is, the making of a thesaurus applied to architecture - with other works on architecture. But developing a thesaurus on architecture doesn't make the developer an architect.

Grant Campbell takes up this statement directly by stressing out, that disciplines and domains have their own terms, practices, traditions, ca- nonical texts but $\mathrm{KO}$ is outside of special domains and has more an iterant role by communicating information between different groups. This reminds me to the fiction of a 'Troubadour of Knowledge' as de Beer (2010) had stated it for the knowledge worker in a new knowledge age with reference to 'Le TiersInstruit' by Michel Serres (1997). In so far this might be already a position for the third question.

Dahlberg explains the origin of the naming of 'Knowledge Organization', which is not at least a part of the name of the society which was founded in 1989 in Germany. They took up the wording 'Organization of Knowledge [in libraries]' of Henry Bliss (1933) but changed it into the shorter 'Knowledge Organization', what is in German an allowable collocation of words. It should describe order activities in classification. In other languages this might be misunderstood, as organization refers to institutions and business aspects. The earlier journal International Classification of the German Society for Classification, which was founded mainly by Dahlberg, was accordingly renamed to Knowledge Organization but the coding system for the bibliography remained exactly the same.

In so far Ohly regards ISKO and KO within its historical and structural boundaries. It emerged from library science cataloging. But the German Society for Classification (GfKI) was founded in contrast to the DGD (German Society for Documentation), with the GfKI as more theoretical and methodological oriented and less stress on documentation praxis. In contrast the ISKO was founded by the non-statistician part of GfKI as a society with less orientation to business informatics. Hereby problems are arising, as it lost its connections to computer-oriented fields, including knowledge management. Hence ISKO and KO have to claim a focus that is not already occupied by other established scientific neighbor communities, e.g., artificial intelligence, neuroscience.

Dahlberg sees KO as a subdiscipline of the Science of Science, what brings it in my view on a critical meta level to other sciences, but underlines in my understanding its more descriptive research orientation (like Scientometrics) and less its fundamental approach. Hjørland (2013) instead sees $\mathrm{KO}$ as a meta science like the science of science, as it has a unique focus, but also with a dependency from subject knowledge:

[...] you cannot classify domains on the basis of theories of knowledge (or other metadisciplines, including genre studies, the sociology of knowledge, etc.) [...] Epistemology is, however, the best general background [...] Concepts and semantic rela- 
tions are not a priori or neutral, but should be examined in relation to their implications for the users they are meant to serve.

Dahlberg underlines that the application fields of $\mathrm{KO}$ are not only in the Information Sciences, but also in all subject fields (domains) needing taxonomies (classification systems of objects). She mentions as examples: statistics, commodities, utilities, weapons, patents, museology, however with the above stated limitation of classification aims. In KO the scientific objects are '(all kinds of) knowledge' and the scientific methods here are the 'organization' principles, that create order of the given kinds of knowledge and its activities.

Babik states the many different definitions of 'knowledge organization' and recommends etymological definitions of its constituent parts 'knowledge' and 'organization'. Only then it becomes more clear what is meant by 'knowledge organization'. In my opinion this includes time and culture dependent definitions. Like Dahlberg, he sees the subjects of $\mathrm{KO}$ as compositions of knowledge. Here information is seen as a raw material for knowledge, but it becomes its meaning from the viewpoint of its organization. As a science of [various aspects of knowledge $\mathrm{KO}$ is for him indispensable to science, education and research, as well as to information science.

Ohly complains that ISKO as a society does not attract a well-defined established profession, like 'Knowledge Organizer' or 'Semantic Worker'. But it has its main application and acceptance in library science. When the focus of KO should be more general one should speak of 'arranging of knowledge' instead of ordering, classification or organization, what has some connotation with rigidity and stability. How far extraction, connection, reasoning, or interpretation of knowledge should be included in the focus of ISKO has carefully to be considered. Are these only some aspects of knowledge, which are treated well in other disciplines or are these the inevitable implications of classification? He misses in the definition of KO: the economic dimension (high quality information implies this), the scientific background of the applied field (which changes the principles of classification) (2), and the sociological aspects (which are relevant for the acceptance of ordering systems, for the social dynamics of use and misuse, and for the development of social software models).

Soergel as well asserts that most ISKO members come out of a library and bibliographic systems tradition, what "presents somewhat a barrier to bring the $\mathrm{KO}$ expertise to the much wider arena where it is applicable and where it would be beneficial". But he rates documentary information only as a part of the information landscape. As other applications of high importance, Soergel names: electronic health records (EHR), scientific data, research networking systems, business information systems, linked data as a format. "To enable transfer of ISKO expertise into these wider application areas and the associated communities requires a re-orientation. ISKO members need to work in other areas [...]"

López-Huertas (2014) and Rodríguez-Bárcenas and López-Huertas (2013) refer e.g., to the importance of $\mathrm{KO}$ in decision making processes. Even more impetus on management relations of $\mathrm{KO}$ is given by the report of the ISKO-Maghreb chapter (Sidhom, 2014a) with respect to the themes of its annual conferences (3):

The challenge of integration of business applications in dematerialized flows is fundamental to avoid breaks in the information processing. The other challenge is to manage in a unified way the whole relationship with the customer or user, regardless of the exchange modes he used, and regardless of the requested resources: data, information, knowledge, know-how and skill.

Even more, the program of the ISKO Maghreb conference 2014 states the important role of context conditions for KO (ISKO Maghreb, 2014):

The governance of knowledge seems to be the Scientific Policy most able to creating value with regard of human and its evolution in cultures and civilizations. The duty of good governance is a consideration of the transfer of knowledge related to scientific and technological progress. Intrinsically, this process requires a system of organization and knowledge management by implementing knowledge production and its influence in society. The objective of the ISKO-Maghreb Chapter is to contribute in understanding the factors that organize knowledge and phenomena that affect the information society.

what could be named as 'Order of Knowledge' or 'Knowledge Order' (c.f. Spinner, 1994).

Gnoli suggests to analyze ISKO resources to identify the scope of KO: the journal Knowledge Organization (1975), the online KO bibliography (ISKO, 1988), and the forthcoming online dictionary/glossary of KO. In his definition e.g. 'KO events' should deal with the subject content of documents in a broad sense of document, not just in libraries but independently from the technical means and carriers it addresses. He refers to Buckland (2014) who sees a trend to "ubiquitous recording, pervasive representations, simultaneous interaction regardless of geography, and powerful analysis and visualization of the 
records resulting from that ubiquitous recording". $\mathrm{He}$ votes for 'conceptual interoperability' (conceptual mapping, SKOS, OWL, etc.) as field of $\mathrm{KO}$, in contrast to technical interoperability. Therefore developments of the semantic web should be included in $\mathrm{KO}$. KO is often named with other terms in the field of ontology, taxonomy, terminology, topic maps, information architecture, etc. Here KO is often not identified as a field in itself, as basic logical components of knowledge (classes, hierarchies, terms, etc.) are often taken for granted. What is lacking is a common, consistent terminology in this field. He prefers the view of 'dimensions of KO' (ontological, epistemological, pragmatic, etc.).

As summary of the question 'What is KO?' we can state that the main focus is order activity or classification. As such it has a meta view on the subjects it deals with and has some universal aspects like Science of Science. Nevertheless the focus must be seen wider than classification in library science and take into account wider application areas not at least in informatics though the bridge building function and conceptual dimension seem to be its main merit.

\section{What changes do you foresee in the future that will prove to be the most challenging for ISKO?}

Already in the previous chapter when the panel tried to shape KO some statements concerned future challenges and recommendations for the future: the itinerant role of $\mathrm{KO}$ (Campbell), the lacking computer orientation, application orientation, economic and social aspects, professionalization (Ohly), clear terminology (Babik, Gnoli), opening to more than library tradition and diversification (Soergel, Gnoli), semantic web challenges (Gnoli). But the subsequent discussion took up more explicit points.

If knowledge organization should be a scientific discipline in its own right, Dahlberg demands to develop it accordingly and start with elaborating its roots, such as Wuester's work on concepts (DIN 2330 (2013); ISO 704 (2009)—, her contribution on concept definition and concept systems (Dahlberg, 1979; Dahlberg, 2009), her development of an Information Coding Classification (ICC), as well as the fundamental studies of Ranganathan (1967) on faceted classification.

Ohly demands that KO must be more open to realize that there are new applications, new knowledge sources and quite other applications than library cataloging: virtual knowledge generation, mobile devices, decision making, evaluation indexes. By the way: ISKO UK had in November 2014 a meeting on 'Knowledge organi- zation goes mobile' (ISKO UK, 2014). Literacy is wanted on $\mathrm{KO}$ for users from other communities but as well there is a permanent need for understanding new upcoming techniques and thinking in neighboring fields. Openness to understanding and applicability of neighboring disciplines, specialized areas, and other cultures can be strengthened by according tutorials, workshops, and co-operations.

Likewise Lopez-Huertas recommends to invite speakers from other communities to ISKO conferences and to make sure that there is a sufficient number of papers of interest to members of other communities.

And McTavish demands to incorporate better new, different, and upcoming voices, e.g. from students. ISKO should also offer partial conference scholarships to new students. The new ISKO president Tennis in his candidacy statement (2014a) argues similarly for: survey to the membership, convene discussion sessions, working groups. In another contribution (Tennis, 2008) he says:

Our elenchus [rhetoric] is unique, and by acknowledging what is and what it is not, we can see how our work interfaces with myriad research initiatives and the legion of new techniques, tools, and systems of organization.

In the discussion round he argued in the same way "to question what is core and what is peripheral" and to have an "open discussion about these issues" instead of relying on 'canons' that define "what is core and what is peripheral" (Tennis, 2014).

Dodebei sees the problema that with the internet and dynamic approaches we are losing the historical traces of knowledge. This leads over to the question of supporting sustainable knowledge for a 'knowledge society'. Whereas the context is unstable we have to find means to preserve a secured constant knowledge pool, especially in the soft sciences (art, history, anthropology, archeology). Compare with this position Buckland (2014), who states: "The tension between the benefits of technology and the limitations imposed by fixity in a changing world provide a central tension in knowledge organization over time". For Dodebei cultural discussions, concerning e.g. the connected societies, have to be included in ISKO topics.

For David the connected world (with the associated functionalities) changes the way knowledge is acquired, represented, managed and exploited. Hence KO has to care about. But mankind should resist the temptation of research [and methods] that are only technologically driven. Though the statements of San Segundo are not 
published in Green (2014) we can add here her conclusion in 2006 (San Segundo, 2008).

The new organisation of knowledge points to a totally new conception; post-modern epistemology has yet to be articulated. There has been a leap from the invalidity of a general knowledge theory, which culminated in positivist epistemology, to a new digital organisation which is objectively destructured and structured from subjectivity, based on semantic networks instead of lexical similarities, within this process of methodological revolution and, with some new material parameters, the forthcoming millennium invades a new organisational form of knowledge in the digital post-modern universe.

In the same way Campbell sees missions for KO in the future (as well as for other disciplines) to negotiate the demands of different cultures instead of enforcing uniformity, and to think more easily and clearly in terms of sustainability. The next international ISKO congress 2016 in Rio de Janeiro will exactly be devoted to such a theme namely 'Knowledge Organization for a Sustainable World'.

Tennis sees a big potential in looking at other neighbor associations and groups, with their own approaches, terminology, means, and purposes, as classification is a problem solving activity not only in very different kinds of libraries but also by everyone trying to organize digital material (2014).

Babik promotes a network approach to knowledge organization, both in its theoretical and conceptual dimensions as well as in practical ISKO activities. Whereas in the past there was an explicit tendency toward automation, globalization and socialization of information and knowledge creation processes, we have now to come back to more human-oriented and sustainable developments.

The question 'Challeges for ISKO/KO' provoked statements concerning its mission and strategy. ISKO has to contribute to sustainability and human aspects in the information task. KO literacy, openness, interdisciplinarity, and network approaches are seen as demands for the future.

\section{What is your ideal picture of what the ISKO, resp. the KO, of the future could be? How do we get there?}

In the previous question already ideals were formulated (Dahlberg: back to the roots; Ohly, McTavish, Lopez-Huertas: openess; Dodebei, Campbell, Babik: sustainability and humanorientation) and the following explicit question on an ideal ISKO brought up further considerations.
For David the current orientation of ISKO should be maintained and reinforced. "To maintain its level of recognition, the community should remain focused on scientific objects rather than technology-dependent issues." Here one could refer to the 10 desiderata of Dahlberg (2011).

Ridenour favors an open access model of publication to provide access for people who may be interested in $\mathrm{KO}$, but are not part of the community. Especially as "KO literature is both difficult to locate and misindexed in databases such as [Library, Information Science \& Technology Abstracts] LISTA, usually placed under knowledge management" a forum might be helpful to attract more people and to collaborate with individuals in other research specialties.

Babik says that "ISKO and KO will benefit from the implementation of the idea of information and knowledge society, because this process demands high quality information and knowledge". The idea of Knowledge ecology resp. Information ecology (Capurro, 2011) holds as well for KO. He distinguishes for ISKO activities three basic levels: international, national and local. Accordingly the ISKO structure should be developed, like it has been done in the Polish chapter.

Ohly thinks of ISKO as a virtual institute where, like in e-science, projects and advice functions are performed virtually with scientists, coming as well from other disciplines. For him it is more important to explain and elaborate the differences, strengths and weakness of special KO approaches in special applications instead of knowing what is the best KO system.

Tennis sees 'polytely', the complex problemsolving with multiple goals as a concept for ISKO and $\mathrm{KO}$, what implies for him the open dialogue with other disciplines and professions.

\section{For Soergel ISKO would ideally (Green, 2014)}

develop into a society that covers $\mathrm{KO}$ issues in a wide range of applications, with keen attention to common principles, and that attracts people focusing on $\mathrm{KO}$ from many communities, serving as a common meeting point for the transfer of basic knowledge and of reusable modules in the development of KO systems. [...] ISKO should get involved in formulating information literacy standards [...] for deeper understanding of principles of knowledge [...]

One should be aware of the wide range of $\mathrm{KO}$ applications, e.g. CYC Ontology, WordNet, Gene Ontology (GO), SnoMed, etc. - extended by him in Green (2014):

This extension of the range should also be pursued for the journal KO. [...] Finally, it would be useful to 
create a list of associations, conferences, and separate listservs that deal with $\mathrm{KO}$ and also repositories for KOS.

To sum up, ideally $\mathrm{KO}$ and ISKO are seen as an exchange forum that provides access to standards and different approaches in the field of $\mathrm{KO}$, not at least via electronic communication means. Thus it would meet information ecological and complex problem solving demands.

\section{Conclusion: What and How?}

Though the charter of ISKO (1989) mentions "all methods for the organization of knowledge", "especially the conceptual approaches", the practice and attraction of ISKO and subsequently of its field $\mathrm{KO}$ is mainly restricted to the library and documentation science. $\mathrm{KO}$ is stated as a meta science to science, as it is applicable in all science fields and especially has the potential to communicate information between various fields. But the current tendency of mere technical orientation is seen as a threat. Instead semantics and conceptual interoperability should play a bigger part. A common terminology, free access to basic papers, as well as repositories for modules are lacking. Cultural diversity, openness and ploytely as well as high quality information have to be guaranteed by $\mathrm{KO}$, leading to a knowledge ecology. Quite much more application areas must be seen as $\mathrm{KO}$ playing grounds than currently perceived in $\mathrm{KO}$.

\section{Notes}

(1) C. f. the questions in Mcllwaine/Mitchell (2008). 1. Can knowledge organization principles be extended to a broader scope, including hypertexts, multimedia, museum objects, and monuments? 2. Can the two basic approaches, ontological and epistemological, be reconciled? 3. Can any ontological foundation of knowledge organization be identified? 4. Should disciplines continue to be the structural base of knowledge organization? 5 . How can viewpoint warrant be respected? 6 . How can knowledge organization be adapted to local collection needs? 7. How can knowledge organization deal with changes in knowledge? 8. How can knowledge organization systems represent all the dimensions listed above? 9. How can software and formats be improved to better serve these needs? 10. Who should do knowledge organization: information professionals, authors or readers?

(2) C. f. Hjørland, 2013: "[...] In order to achieve good consistent indexing, the indexer must have a thorough appreciation of the structure of the subject and the nature of the contribution that the document is making to the advancement of knowledge [...]"

(3) Sidhom explains in an e-mail discussion, that 'competitive advantage' is the core point for the Maghreb world, whereas library and information science is of minor importance. Accordingly under 'Classification' as main topics are listed: 'Knowledge management' resp. 'Information management' (Sidhom, 2014) - another interpretation of these concepts?

\section{References}

Buckland, Michael K. (2014). Knowledge organization and the technology of intellectual work. // Babik, W.: Knowledge Organization in the 21st Century: Between Historical Patterns and Future Prospects. Proceedings of the 13th International ISKO Conference 19-22 May 2014 Kraków, Poland. Würzburg: Ergon, 2014, 14-21.

Capurro, Rafael (2011). Towards an Information Ecology. // Wormell, I.: Information Quality. Definitions and Dimensions. London: Taylor Graham, 1990, 122-139, updated 2011. http://www.capurro.de/nordinf.htm (2014-11-07).

Dahlberg, Ingetraut (2011). How to improve ISKO's standing: ten desiderata for knowledge organization. // Knowl. Org. 38:1, 68-74.

Dahlberg, Ingetraut (2009). Concepts and terms: ISKO's major challenge. // Knowl. Org. 36 (2009), 2/3, 169-177.

Dahlberg, Ingetraut (1979). On the theory of the concept. // Neelameghan, A.: Ordering Systems for Global Information Networks; Proceedings of 3rd International Conference on Classification Research, Bombay, India, January 6-11, 1975. Bangalore: Sarada Ranganathan Endowment for Library Science, 1979, 54-63.

De Beer, Carel S. (2010). The troubadour of knowledge: a knowledge worker for the new knowledge age. // Paradigms and conceptual systems in knowledge organization: Proceedings of the 11th International ISKO Conference. Würzburg: Ergon, 2010, 430-437.

DIN 2330 (1993). Begriffe und Benennungen - Allgemeine Grundsätze (concepts and designations - general principles). Berlin: Beuth, 1988, updated: 1993, 2013.

Green, Rebecca (2014). ISKO and Knowledge Organization's 25th Anniversary: The Future of Knowledge Organization and ISKO. Panel Discussion. // Knowl. Org. 41 (2014), no. 4, 327-331. See also: http://iskobrasil.org.br/wp-content/uploads/2014/06/relat_iskoCrac \%C3\%B3via2014.pdf (2014-11-07).

Hjørland, Birger (2013). Theories of knowledge organization - Theories of knowledge. // Knowl. Org. 40:3, 169-81.

ISO 704 (2009). Terminology work - Principles and methods. 2000, updated: Geneva: International Organization for Standardization, 2009.

ISKO (1988). Knowledge organization literature. http://www.isko.org/lit.html (2014-11-07).

ISKO (1989). ISKO charter and premable. http://www.isko.org/charter.pdf (2014-11-07).

ISKO (2004). International Society for Knowledge Organization. http://www.isko.org (2014-11-07).

ISKO Maghreb (2014). ISKO Maghreb conference 2014 Program. http://iskomaghreb2014.cerist.dz/index.php? lang=en (2014-11-07).

ISKO UK (2014). Knowledge Organization goes mobile. Wednesday, 5th November 2014. http://www.iskouk. org/events/mobileKO_Nov_2014.htm (2014-11-07).

Knowledge Organization / ISKO. Frankfurt, Ergon Verlag, 1993. ISSN 0943-7444. http://www.isko.org (2014-1107).

López-Huertas, Maria J. (2014). Exploring the boundaries of knowledge organization. Towards future projects. // Babik, W.: Knowledge Organization in the 21st Century: Between Historical Patterns and Future Prospects. Proceedings of the 13th International ISKO Conference 1922 May 2014 Kraków, Poland. Würzburg: Ergon, 2014, 564-571.

Mcllwaine, la C.; Mitchell, Joan S. (2008). Preface to Special Issue. 'What is Knowledge Organization'. // Knowl. Org. 35 (2008), no. 2/3. 
Ranganathan, Shiyali R. (1967). Prolegomena to Library Classification. // The Five Laws of Library Science 1967, 1-73. http://arizona.openrepository.com/arizona/handle/ 10150/106370 (2014-11-07)

Rodríguez-Bárcenas, Gustavo; López-Huertas, María J. (2013). Saaty's analytic hierarchies method for knowledge organization in decision making. // Journal of the American Society for Information Science and Technology, Volume 64 (2013), 7 (July), 1454-1467.

San Segundo Manuel, R. (2008). From the invalidity of a general classification theory to a new organization of knowledge for the millennium to come. // Ohly, H. P.; Netscher, S.; Mitgusch, K.: Kompatibilität, Medien und Ethik in der Wissensorganisation (Compatability, media and ethics in knowledge organization). Proceedings of the 10. conference of the German ISKO, Vienna, July 2006, Ergon: Würzburg 2008, 12-17.

Serres, Michel (1997). Le Tiers-Instruit. Pans: Editions Francois Bounn, 1991. (published in English as: The Troubadour of Knowledge, University of Michigan Press, 1997)

Sidhom, Sahbi (2014). e-mail 'Re: CfP: 4th Int. SymISKO Maghreb' sent to the Executice Committee of ISKO, 27th Jan. 2014.
Sidhom, Sahbi (2014b). ISKO-Maghreb (Tunisia, Algeria \& Morocco) chapter Report May 2014, sent per e-mail to ISKO Executive Committee 16th May 2014.

Spinner, Helmut (1994). Die Wissensordnung: Ein Leitkonzept für die dritte Grundordnung des Informationszeitalters. Opladen: Leske and Budrich, 1994.

Tennis, Joseph T (2014). Canons, Affiliations, and Polytely: The Future of Knowledge Organization and ISKO. (unpuplished presentation for the 13th international ISKO conference, Krakow, May 2014)

Tennis, Joseph T. (2014a). Candidacy Statements: Listen, Deliberate, Act (2014). http://www.isko.org/president 2014tennis.pdf

Tennis, Joseph T. (2008). Epistemology, Theory, and Methodology. in Knowledge Organization: Toward a Classification, Metatheory, and Research Framework. // Knowl. Org. 35:2/3, 102-112. http://faculty.washington.edu/jten nis/Publications_files/Tennis2008KOEpist.pdf.

Enviado: 2014-11-05

Aceptado: 2015-01-12. 
